\title{
Trial Disease Offset From Reference
}

National Cancer Institute

\section{Source}

National Cancer Institute. Trial Disease Offset From Reference. NCI Thesaurus. Code C117702.

The difference between a point and a fixed reference point of a trial disease assessment. 